\title{
THE ENGINEER IN COMMONWEALTH DEVELOPMENT
}

\begin{abstract}
LITTLE reflexion might suggest that it is perhaps a strange way to honour the achievements of distinguished men by inviting them to accept a presidency which involves a presidential address before a distinguished, but highly critical, audience or to give a named lecture which, because of the special circumstances, likewise attracts wide publicity. Many a famous scientist has emerged from such an ordeal with an impaired rather than an enhanced reputation; the specialist venturing outside the sphere in which he is an acknowledged master is too often apt to be trite or banal. On the other hand, such an occasion affords a great opportunity to present to an influential audience a considered synthesis which may well bear important fruit.
\end{abstract}

H.R.H. the Duke of Edinburgh is one who rises magnificently to such occasions. No one who heard his presidential address to the British Association at Edinburgh in 1951 could doubt his ability to take the broad, balanced view, based with meticulous care on carefully collected and assimilated facts, and to present his material in such a way as to shame the professional lecturer. This year he was invited jointly by the three great engineering institutionsthe Civil, Mechanical and Electrical-to give the seventh Graham Clark Lecture on April 13. The first plan was a survey of "Resources, Human and Material, of the Commonwealth". The basic material was assembled and has been published as a series of statistical tables separately printed as appendixes to the lecture. A wide range of standard sourcesin each case the best available - has been used and combined with the results of a number of specific inquiries (especially through the Commonwealth Economic Committee). Throughout these tables the emphasis is on a comparison between the Common. wealth (with countries separately named but including at this date the Union of South Africa) and the world as a whole. Population, labour force, land use, value of agricultural produce, energy production and consumption, primary production, mineral output, mineral reserves, transport and education are included in turn. The whole affords a simple yet effective view of how the Commonwealth stands in relation to the world as a whole.

But, as the Duke so rightly says, "resources are not very interesting until you start doing things to them". Since engineers play a dominant part in this, "I have tried to outline the engineer's part in the various fields of development and some of the opportunities and problems" of the profession. "The engineer is in fact the means by which the people are able to enjoy the fruits of seience, whether in building now projects, or in maintaining and keeping up to date what is already in existence."

It is rumoured that the presidential address to the British Association was composed-and that is the right word-on the backs of naval signal forms during moments of hard-earned leisure in the chart room or on the bridge of a ship of the Royal Navy on active service. Incredible as it may seem that there were in fact moments of leisure during the recent royal tour to India and Pakistan, by his own confes- sion the Graham Clark Lecture was similarly composed. One result is a particularly felicitous blend of library research and field observations. It may truthfully be said that no living person is better equipped to produce such a survey. No one has travelled the Commonwealth, from Antarctic to tropics, more widely yet always on duty, his hosts ever anxious to show everything worth while, their guest, always alert to note and record, not so much the detail, as the overall picture.

How does the Commonwealth stand in relation to the rest of the world? With 23 per cent of the land surface and 24 per cent of the population, the existence of 44 per cent of the land unused is a challenge since in food production the figures are not impressive. Only rice (24 per cent), barley (20 per cent) and mutton (23 per cent) are produced in proportion to land and population. It is freely admitted that the picture of the Commonwealth as a whole is distorted by the extreme contrasts between its constituent parts such as Britain and India, and the fact that India-Pakistan have 68 per cent of the total people. Nevertheless, the conclusion seems inevitable that the Commonwealth is at present not producing according to potential. 20 per cent of the world's rain falls on Commonwealth lands; Kariba and Volta are projects now in hand but the Hamilton Falls are unused and, taking energy as a whole-coal, oil, water-power-the Commonwealth's share in output is less than 12 per cent.

His Royal Highness comments, somewhat ruefully, that he has to bear criticism rather more frequently than most, and suggests that a little mild and wellintentioned criticism should be treated as a sign post rather than as a slander. His comments, though forthright, are scarcely criticisms and are so obviously sincere and well-founded as to command respect. There is the old argument involving 'pure' and 'applied' science-by implication the latter also 'impure'-and it is still true that academic honours, for example, the fellowship of the Royal Society, are more hardly won by the applied scientist. Yet who deserves the greater credit: he who conceives an idea in a laboratory or he who with infinite pains adapts and refines it to the benefit of countless num. bers of mankind? "We are apt to forget that much scientific research is only possible with the aid of very advanced engineering; computers, electron microscopes . . . are no longer bits of apparatus that can be knocked up in the lab." It is refreshing, too, to be reminded that our united aim should be to benefit mankind. "Unless large-scale projects and modernization plans are based upon a practical humanity they will contribute very little to man's progress." Or again, "it is becoming increasingly popular to look upon industry merely as a convenient way of giving employment ... it has to satisfy the needs and desires of the individual". It is clear the Duke would not happily agree with those who go so far as to declare that the possession of resources is of little importance compared with the possession of capital with which to develop them. Such a view is economic colonialism at its worst and, by not 
referring to either political or economic aspects of development, he makes the obvious assumption that mankind should be the master and not the slave of its own social and economic systems.

Coming from a world traveller, we have timely reminders of the importance of communications and of scale so difficult to judge in small countries such as Britain-five times as far across mainland Canada and twice as far from Bom. bay to Calcutta as from John o'Groats to Land's End.

Seeing the Duke's interest in youth, it is not surprising that he is far from happy regarding the adequacy of higher education in technical fields. The appeal for forward thinking is well timed and, like every other aspects of life brought into this stimulating address, merits the closest attention.

L. Dudley Stamp

\section{THE U.S. ACADEMY OF SCIENCES \\ OFFICERS, MEDAL AWARDS AND NEW MEMBERS}

$\mathrm{D}^{\mathrm{n}}$ R. J. A. STRATTON, president of Massachusetts Institute of Technology, has been elected to a four-year term as vice-president of the U.S. National Academy of Sciences. Dr. G. B. Kistiakowsky, Abbott and James Lawrence professor of chemistry, Harvard University, and Dr. Kenneth B. Raper, professor of bacteriology and botany, University of Wisconsin, have been appointed members of Council for a term of three years.

The following medal awards have been made: the Henry Draper Medal, for original investigation in astronomical physics, to Dr. Martin Schwarzschild, Princeton University Observatory; the Daniel Giraud Elliot Medal, for meritorious work in zoology or palæontology published each year, to Philip J. Darlington, jun., Museum of Comparative Zoology, Harvard University; the Kimber Genetics Medal, for achievement in the science of genetics, to Prof. J. B. S. Haldane, (recently) Indian Statistical Institute, Calcutta; the Jessie Stevenson Kovalenko Medal, for contributions to medical science, to Dr. K. F. Meyer, George Williams Hooper Foundation, University of California; the Mary Clark Thompson Medal, for services to geology and palæontology, to Dr. Norman D. Newell, American Museum of Natural History; the James Craig Watson Medal, for noteworthy discoveries or research in astronomy, to Prof. Otto Heckmann, Hamburg-Bergedorf Observatory.

The following new members have been elected: Prof. D. I. Arnon, professor of plant physiology, University of California; Dr. W. O. Baker, vicepresident in charge of research, Bell Telephone Laboratories; Prof. S. Benzer, professor of biophysics, Purdue University; Dr. H. A. Borthwick, principal plant physiologist, Agricultural Research Service, U.S. Department of Agriculture; Prof. R. H. Burris, professor of biochemistry, University of Wisconsin; Prof. Shiing-Shen Chern, professor of mathematics, University of California at Berkeley; Dr. P. E. Cloud, jun., chief, Paleontology and Stratigraphy Branch, U.S. Geological Survey; Prof. J. H. Comroe, jun., director of the Cardiovascular Research Institute and professor of physiology,
University of California Medical Center; Prof. D. J. Cram, professor of chemistry, University of California; Prof. J. F. Crow, professor of zoology and genetics, University of Wisconsin; Dr. L. S. Darken, associate director, research laboratory, United States Steel Corporation; Prof. C. Djerassi, professor of chemistry, Stanford University; Prof. W. Von Eggers Doering, professor of chemistry, Yale University; Prof. R. Dulbecco, professor of biology, California Institute of Technology; Prof. A. I. Hallowell, professor of anthropology, University of Pennsylvania; Prof. B. L. Horecker, professor of microbiology, New York University College of Medicine; Prof. R. D. Hotchkiss, member, and professor of cellular physiology, Rockefeller Institute; Dr. Libbie H. Hyman, research associate, American Museum of Natural History; Prof. M. G. Inghram, professor of physies, University of Chicago; Prof. W. N. Lipscomb, jun., professor of chemistry, Harvard University; Dr. H. F. Mark, director, Polymer Research Institute, Polytechnic Institute of Brooklyn; Prof. H. Neurath, professor of biochemistry, University of Washington; Prof. G. E. Palade, member, and professor of cytology, Rockefeller Institute; Prof. R. V. Pound, professor of physics, Harvard University; Prof. L. A. Riggs, professor of physiological psychology, Brown University; Dr. R. B. Roberts, chairman, Biophysics Section, Department of Terrestrial Magnetism, Carnegie Institution of Washington; Prof. Per F. Scholander, professor of physiology, Scripps Institution of Oceanography; Dr. C. D. Shane, astronomer, Lick Observatory; Prof. D. C. Spencer, professor of mathematics, Princeton University; Mr. H. M. Stommel, research associate in physical oceanography, Woods Hole Oceanographic Institution; Prof. Leo Szilard, professor of biophysics, University of Chicago; Prof. J. W. Tukey, professor of mathematics, Princeton University; Prof. F. T. Wall, research professor of physical chemistry, University of Illinois; Dr. A. M. Weinberg, director, Oak Ridge National Laboratory; Prof. J. H. Williams, professor of physics, University of Minnesota.

\section{OBITUARIES}

\section{Sir William Savage}

THe death of Sir William Savage in his eightyninth year on April 6,1961, means the passing of the last survivor of that distinguished company of medical officers of health who contributed so largely to the progress of public health in the late nineteenth and early part of the present century.

William George Savage, the son of John H. Savage, was born in Jamaica in 1872. He was educated privately, at University College, London, and University College Hospital. He took the B.Sc.(Lond.) 